\title{
PHOSPHORYLATION OF CYTARABINE WITH CYCLO-TRIPHOSPHATE IN AQUEOUS SOLUTION
}

\author{
Takuma Kusuhara, Hideko Maeda ${ }^{*}$, Mitsutomo Tsuhako, \\ Hirokazu Nakayama
}

(i-hideko@kobepharma-u.ac.jp)

Department of Functional Molecular Chemistry, Kobe Pharmaceutical University, 4-19-1 Motoyamakita-machi, Higashinada-ku, Kobe 658-8558 Japan.

Keywords: Phosphorylation; Cytarabine; cyclo-Triphosphate; HPLC; ${ }^{31} \mathrm{P}$ NMR

Phosphorylation of cytarabine has been achieved using inorganic cyclo-triphosphate $\left(\mathrm{P}_{3 \mathrm{~m}}\right)$ in aqueous solution. The optimum condition for the phosphorylation of cytarabine with $\mathrm{P}_{3 \mathrm{~m}}$ is cytarabine : $\mathrm{P}_{3 \mathrm{~m}}=1: 10, \mathrm{pH} 12$ and $25^{\circ} \mathrm{C}$. Cytarabine 5'-triphosphate, cytarabine 3'-triphosphate, and cytarabine 2'-triphosphate were synthesized with the total yield of more than $75 \%$. The phosphorylated products of cytarabine were stable in neutral and alkaline solution. The reaction mechanism of cytarabine with $\mathrm{P}_{3 \mathrm{~m}}$ was discussed.

(Received December 18, 2010; Accepted February 15, 2010)

\section{INTRODUCTION}

Synthesis and biological evaluation of nucleotide analogs have been continued for capability of delivering the corresponding nucleotides ${ }^{1-3}$. 9- $\beta$-D-Arabinofuranosyl-cytosine (cytarabine or ara-C) has been applied to many kinds of cancer, but a strong side effect is a serious problem. Cytarabine is expected to possess higher solubility by the introduction of phosphoryl group. So it would be drained outside of the body quickly and then a side effect would be reduced.

Sodium cyclo-triphosphate, $\mathrm{Na}_{3} \mathrm{P}_{3} \mathrm{O}_{9}\left(\mathrm{P}_{3 \mathrm{~m}}\right)$, is a simple and efficient phosphorylating agent. One of the authors reported the phosphorylation of nucleosides ${ }^{4}$ and nucleotides ${ }^{5}$ by $\mathrm{P}_{3 \mathrm{~m}}$. The 2 '- and 3'-OH groups of the $\beta$-D-ribofuranosyl unit on nucleosides and nucleotides were selectively phosphorylated. The main phosphorylated products were 2'- and 3'-monophosphate esters of the nucleosides and nucleotides. However, 2'-deoxyadenosine and 3'-deoxyadenosine could not be phosphorylated at all because of the absence of hydroxyl groups at 2'- or 3'-position of the $\beta$-D-ribose. Also, the reactivity of nucleosides and nucleotides strongly depend on the configuration of the hydroxyl groups at C-2' and C-3'. It is important to apply this selective phosphorylation reaction to other related nucleosides and nucleotides.

In this study, the reaction of cytarabine (the hydroxyl groups at C-2' and C-3' are in trans position) with $\mathrm{P}_{3 \mathrm{~m}}$ was examined to develop a selective phosphoylation.

\section{RESULTS AND DISCUSSION}

\section{Reaction of cytarabine with $P_{3 m}$}

The phosphorylation of cytarabine with $\mathrm{P}_{3 \mathrm{~m}}$ was performed in aqueous solution. Figure 1 shows the HPLC profiles for the reaction solution of cytarabine $(0.06 \mathrm{M})$ and $\mathrm{P}_{3 \mathrm{~m}}(0.6 \mathrm{M})$ incubated at $\mathrm{pH} 12$ at $25^{\circ} \mathrm{C}$. The peak of the product appeared at a retention time of about 14 and $16 \mathrm{~min}$. The total yield of products increased gradually with reaction time to reach the maximum of $75 \%$ after $25 \mathrm{~d}$ and was constant until $60 \mathrm{~d}$ without hydrolysis of product.

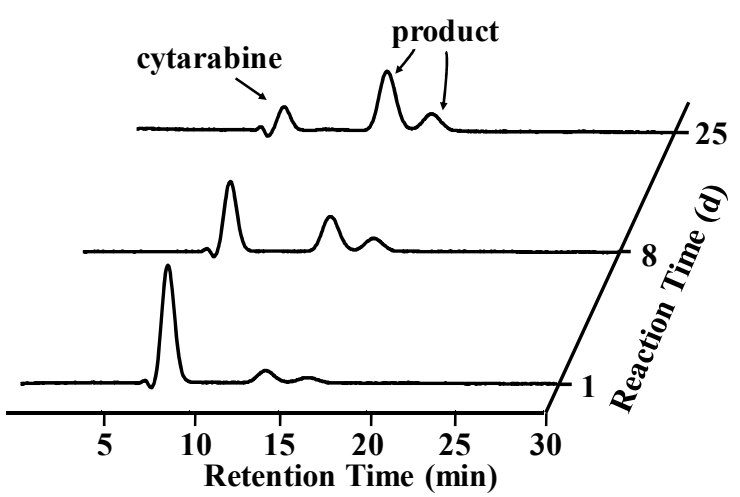

FIGURE 1 HPLC profiles of the reaction solution of cytarabine : $\mathrm{P}_{3 \mathrm{~m}}=0.06 \mathrm{M}: 0.6 \mathrm{M}$ at $\mathrm{pH} 12$ and 25 ${ }^{\circ} \mathrm{C}$

Table 1 summarizes the total yield of products 1 3 under various reaction conditions. Although the HPLC profiles showed two peaks due to the reaction product at the retention time of 14 and $16 \mathrm{~min}$, the 
products are three triphosphate esters $(\mathbf{1}, \mathbf{2}$, and $\mathbf{3})$ as evidenced by the ${ }^{31} \mathrm{P}$ NMR data.

At a pH 12, $25{ }^{\circ} \mathrm{C}$, and a molar ratio of cytarabine : $\mathrm{P}_{3 \mathrm{~m}}=1: 20(0.03 \mathrm{M}: 0.6 \mathrm{M}), 1: 10$ $(0.06 \mathrm{M}: 0.6 \mathrm{M}), 1: 5 \quad(0.12 \mathrm{M}: 0.6 \mathrm{M})$, or $1: 2$ $(0.3 \mathrm{M}: 0.6 \mathrm{M})$, the total yield of products $1-3$ were $73,75,67$, and $60 \%$, respectively. One of us already reported that the reaction of adenosine $e^{4}$ and $\mathrm{P}_{3 \mathrm{~m}}$. The molar ratio for the phosphorylation of adenosine with $\mathrm{P}_{3 \mathrm{~m}}$ is adenosine : $\mathrm{P}_{3 \mathrm{~m}}=0.05 \mathrm{M}: 0.5$ $\mathrm{M}$, that is, $\mathrm{P}_{3 \mathrm{~m}}$ excess. Therefore, a molar ratio of cytarabine : $\mathrm{P}_{3 \mathrm{~m}}=1: 10$ is preferable. At a molar ratio of $1: 10$ and $25^{\circ} \mathrm{C}$, the total yield of products 1 - 3 were $66 \%$ at $\mathrm{pH} 12.5,75 \%$ at $\mathrm{pH} 12$, and $13 \%$ at $\mathrm{pH}$ 10. It was thought that the reaction is easier than at $\mathrm{pH} 12$ rather than $\mathrm{pH} 10$ because proton of $\mathrm{OH}$ group of arabinofuranose unit is easy to dissociate. Therefore, $\mathrm{pH} 12$ is suitable $\mathrm{pH}$. At a molar ratio of 1 : 10 and $\mathrm{pH} \mathrm{12,} \mathrm{the} \mathrm{total} \mathrm{yield} \mathrm{of} \mathrm{products} \mathbf{1}-\mathbf{3}$ were $75 \%$ at $25^{\circ} \mathrm{C}, 64 \%$ at $40{ }^{\circ} \mathrm{C}$, and $20 \%$ at $70{ }^{\circ} \mathrm{C}$. The yield at $25{ }^{\circ} \mathrm{C}$ remained constant after $56 \mathrm{~d}$ without hydrolysis of triphosphate derivative. However, the yield at $40{ }^{\circ} \mathrm{C}$ increased with the reaction time, reaching $64 \%$ after $19 \mathrm{~d}$, and then decreased gradually. Therefore, $25^{\circ} \mathrm{C}$ is preferable temperature. Consequently, the optimum condition for the phosphorylation of cytarabine with $\mathrm{P}_{3 \mathrm{~m}}$ is cytarabine : $\mathrm{P}_{3 \mathrm{~m}}=1: 10, \mathrm{pH} 12$ and $25^{\circ} \mathrm{C}$.

TABLE 1 Total yield of products $\mathbf{1}$ - $\mathbf{3}$

\begin{tabular}{|c|c|c|c|c|c|}
\hline \multicolumn{5}{|c|}{ Reaction conditions } & \multirow{3}{*}{$\begin{array}{c}\text { Total } \\
\text { Yield } \\
(\%)\end{array}$} \\
\hline \multicolumn{2}{|c|}{ Conc. $(\mathrm{M})$} & \multirow{2}{*}{$\mathrm{pH}$} & \multirow{2}{*}{$\begin{array}{c}\text { Temp. } \\
\left({ }^{\circ} \mathrm{C}\right)\end{array}$} & \multirow{2}{*}{$\begin{array}{l}\text { Time } \\
\text { (d) }\end{array}$} & \\
\hline Cytarabine & $\mathrm{P}_{3 \mathrm{~m}}$ & & & & \\
\hline 0.03 & 0.6 & 12 & 25 & 15 & 73 \\
\hline \multirow[t]{5}{*}{0.06} & 0.6 & 10 & 25 & 33 & 13 \\
\hline & & 12 & 25 & 25 & 75 \\
\hline & & 12.5 & 25 & 14 & 66 \\
\hline & & 12 & 40 & 19 & 64 \\
\hline & & 12 & 70 & 8 & 20 \\
\hline 0.12 & 0.6 & 12 & 25 & 17 & 67 \\
\hline 0.30 & 0.6 & 12 & 25 & 15 & 60 \\
\hline
\end{tabular}

To identify the reaction product in the phosphorylation of cytarabine with $\mathrm{P}_{3 \mathrm{~m}},{ }^{31} \mathrm{P}$ and ${ }^{1} \mathrm{H}$ NMR spectra were measured. As shown in Fig. 2, the ${ }^{31} \mathrm{P}$ NMR spectrum with ${ }^{1} \mathrm{H}$-nondecoupling of reaction solution of cytarabine with $\mathrm{P}_{3 \mathrm{~m}}$ indicated that the products are three triphosphate esters $(\mathbf{1}, \mathbf{2}$, and $\mathbf{3})$, although the HPLC profiles showed two peaks due to the reaction product. The ${ }^{1} \mathrm{H}$ non-decoupling spectrum had a doublet of triplet at $-9.6 \mathrm{ppm}$, a doublet of doublet at -10.6 , and a doublet of doublet at $-11.5 \mathrm{ppm}$. Their peaks became doublet on ${ }^{1} \mathrm{H}$ decoupling, which is characteristic for $\mathrm{P}_{\alpha}$. The doublets at $-4.57,-4.62$, and $-4.74 \mathrm{ppm}$ were assigned to the end phosphorus atom $\left(\mathrm{P}_{\gamma}\right)$. The other doublet of doublet around $-20.0 \mathrm{ppm}$ is the characteristic of the middle phosphorus atom $\left(\mathrm{P}_{\beta}\right)$ of triphosphate. A previous work indicated that the phosphorylation product of aminoalcohols ${ }^{6}$ or carbohydrates ${ }^{7-13}$ with $\mathrm{P}_{3 \mathrm{~m}}$ is triphosphate esters or aminoalcohols or carbohydrates with a $-\mathrm{O}-\mathrm{P}_{\alpha}-\mathrm{O}-$ bond. These products show a characteristic $\mathrm{P}_{\alpha}$ signal around $-10 \mathrm{ppm}$ in their ${ }^{31} \mathrm{P}$ NMR spectra. In order to assign the site of phosphorylation, ${ }^{31} \mathrm{P}-{ }^{1} \mathrm{H}$ heteronuclear multiple bond correlation spectroscopy (HMBC) 2D-NMR spectrum was measured.

Figure 3 shows the ${ }^{31} \mathrm{P}-{ }^{1} \mathrm{H}$ HMBC $2 \mathrm{D}-\mathrm{NMR}$ spectrum of products $\mathbf{1}-\mathbf{3}$. The peaks at -9.6 , -4.74 , and -20.0 ppm of the ${ }^{31}$ P NMR spectrum were assigned to product 1 . A correlation of $\mathrm{P}_{\alpha}$ at -9.6 ppm of product 1 and ${ }^{1} \mathrm{H}$ signal at 4.15 and $4.18 \mathrm{ppm}$. The multiplets at 4.15 and $4.18 \mathrm{ppm}$ could be assigned to $\mathrm{H}_{\mathrm{A}}-5$ ' and $\mathrm{H}_{\mathrm{B}}-5$ 'of product 1 . The down-field shift from 3.73 and $3.81 \mathrm{ppm}$ due to cytarabine itself to 4.15 and $4.18 \mathrm{ppm}$ indicates the phosphorylation of cytarabine with $\mathrm{P}_{3 \mathrm{~m}}$. This assignment was confirmed by ${ }^{1} \mathrm{H}-{ }^{1} \mathrm{H}$ COSY NMR spectrum. The ${ }^{3} J_{\mathrm{P} \alpha}, \mathrm{H} 5$, value was $5.4 \mathrm{~Hz}$, which is obtained from the ${ }^{31} \mathrm{P}$ NMR data. Therefore product 1 was verified to be cytarabine 5'-triphosphate.

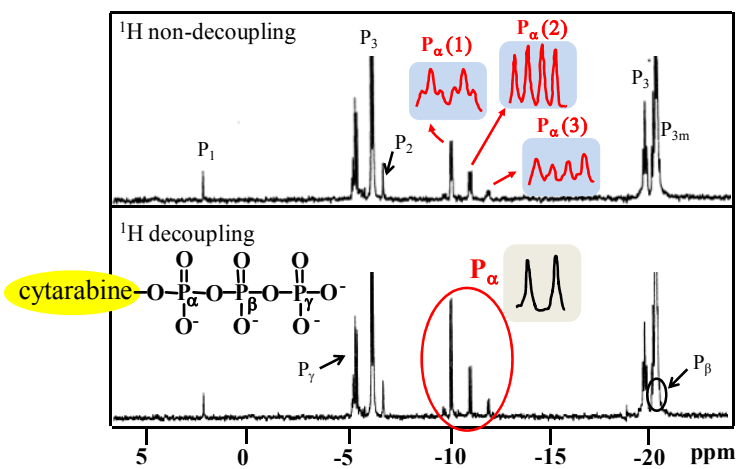

FIGURE $2{ }^{31} \mathrm{P}$ NMR spectra of reaction solution of cytarabine : $\mathrm{P}_{3 \mathrm{~m}}=0.06 \mathrm{M}: 0.6 \mathrm{M}$ at $\mathrm{pH} 12,25{ }^{\circ} \mathrm{C}$, and $25 \mathrm{~d}$

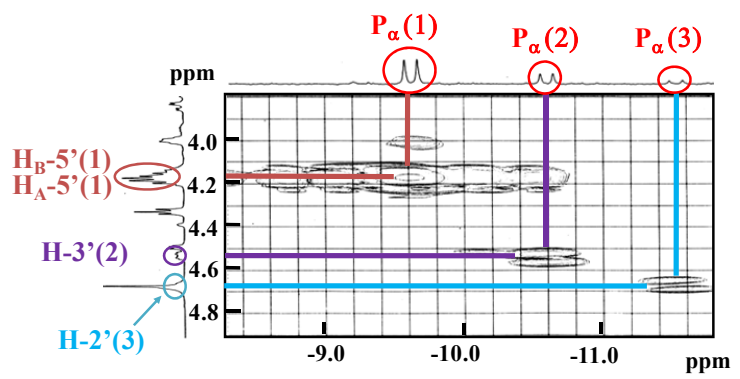

FIGURE $3{ }^{31} \mathrm{P}-{ }^{1} \mathrm{H}$ 2D-NMR spectrum of products $\mathbf{1}$ $-3$

cytarabine : $\mathrm{P}_{3 \mathrm{~m}}=0.06 \mathrm{M}: 0.6 \mathrm{M}, \mathrm{pH} 12,25{ }^{\circ} \mathrm{C}, 25 \mathrm{~d}$

The other peaks at $-10.6,-4.62$, and $-20.0 \mathrm{ppm}$ of the ${ }^{31} \mathrm{P}$ NMR spectrum were assigned to product 2 . A correlation of $\mathrm{P}_{\alpha}$ at $-10.6 \mathrm{ppm}$ of product 2 and ${ }^{1} \mathrm{H}$ signal at 4.53 ppm is shown in Fig. 3. The doublet 
of doublets of doublets at $4.53 \mathrm{ppm}$ was assigned to $\mathrm{H}-3$ ' based on ${ }^{1} \mathrm{H}-{ }^{1} \mathrm{H}$ COSY NMR spectrum. The down-field shift from $4.01 \mathrm{ppm}$ due to cytarabine itself to $4.53 \mathrm{ppm}$ indicates the phosphorylation of cytarabine with $\mathrm{P}_{3 \mathrm{~m}}$. Therefore product 2 was verified to be cytarabine 3'-triphosphate.

The other peaks at $-11.5,-4.57$, and $-20.0 \mathrm{ppm}$ of the ${ }^{31}$ P NMR spectra were assigned to product 3 . A correlation of $\mathrm{P}_{\alpha}$ at $-11.5 \mathrm{ppm}$ of product 3 and ${ }^{1} \mathrm{H}$ signal at $4.67 \mathrm{ppm}$ is shown in Fig. 3. The multiplet at $4.67 \mathrm{ppm}$ was assigned to $\mathrm{H}-2$ ' based on ${ }^{1} \mathrm{H}-{ }^{1} \mathrm{H}$ COSY NMR spectrum. The down-field shift from $4.29 \mathrm{ppm}$ due to cytarabine itself to $4.67 \mathrm{ppm}$ indicates the phosphorylation of cytarabine with $\mathrm{P}_{3 \mathrm{~m}}$. Therefore product $\mathbf{3}$ was verified to be cytarabine 2'-triphosphate.

\section{Reaction mechanism of cytarabine with $P_{3 m}$}

The reaction of cytarabine with $\mathrm{P}_{3 \mathrm{~m}}$ may be explained by the following mechanism. At $\mathrm{pH} \mathrm{12,}$ $\mathrm{P}_{3 \mathrm{~m}}$ is easily attacked by nucleophilic reagents such as amines ${ }^{6}$, amino acids ${ }^{14}$ and cyclodextrins ${ }^{13}$. In the present study, the lone electron pair on the hydroxyl group of cytarabine nucleophilically attacks a phosphorus atom of $\mathrm{P}_{3 \mathrm{~m}}$ to cleave its six-membered ring (Scheme 1). The 2'-OH, 3'-OH, or 5'-OH of $\beta$-D-arabinofuranose unit reacts with $\mathrm{P}_{3 \mathrm{~m}}$ to form cytarabine 5'-triphosphate (1), cytarabine 3'-triphosphate (2), and cytarabine 2'-triphosphate (3). Previous works showed that the hydroxyl groups at C-5' of nucleosides and nucleotides could not react with $\mathrm{P}_{3 \mathrm{~m}}$, and C-2' and C-3' of them which are in cis position react with $\mathrm{P}_{3 \mathrm{~m}}$ to form monophosphate esters ${ }^{4,5}$. On the other hand, cytarabine, in which the hydroxyl groups at C-2' and C-3' are in trans position reacts with $\mathrm{P}_{3 \mathrm{~m}}$ to form triphosphate esters (1, 2, and $\mathbf{3}$ ).

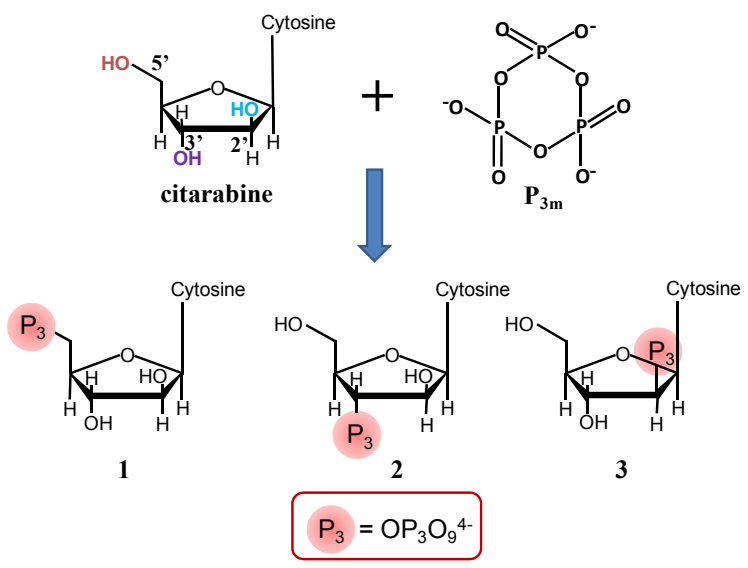

SCHEME 1 Reaction mechanism of cytarabine with $\mathrm{P}_{3 \mathrm{~m}}$

\section{Stability of phosphorylated cytarabine}

Figure 4 shows the changes of the amount of phosphoryated products at $\mathrm{pH} 2,7$, and 12 . The products were synthesized under the reaction condition of $\mathrm{pH} 12,25{ }^{\circ} \mathrm{C}$, and a molar ratio of cytarabine : $\mathrm{P}_{3 \mathrm{~m}}=0.06 \mathrm{M}: 0.6 \mathrm{M}$ for $25 \mathrm{~d}$. At $\mathrm{pH} 2$, phosphorylated products were decomposed gradually and decreased to $38 \%$ after 50 days. On the other hand, phosphorylated products were stable at $\mathrm{pH} 12$ for 30 days, but after $30 \mathrm{~d}$ they were decomposed gradually. However, it was stable at $\mathrm{pH} 7$ for 56 days. Therefore, phosphorylated products of cytarabine were stable in neutral and alkaline solution.

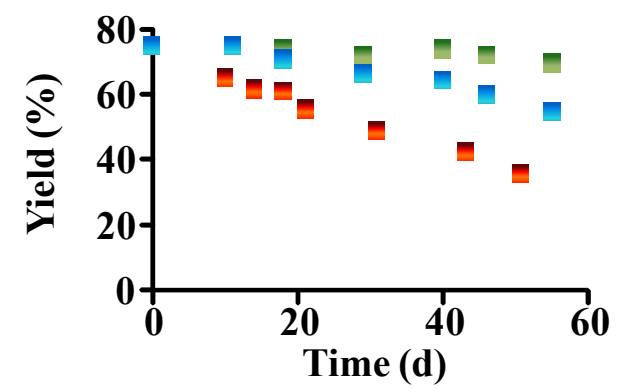

FIGURE 4 Stability of phosphorylated cytarabine synthesized under the condition of cytarabine : $\mathrm{P}_{3 \mathrm{~m}}=$ $0.06 \mathrm{M}: 0.6 \mathrm{M}, \mathrm{pH} 12,25{ }^{\circ} \mathrm{C}$, and $25 \mathrm{~d}$

: pH 2, : $: \mathrm{pH} \mathrm{7,}: \mathrm{pH} 12$

\section{Conclusion}

In the reactions of cytarabine with $\mathrm{P}_{3 \mathrm{~m}}$, cytarabine 5'-triphosphate (1), cytarabine 3'-triphosphate (2), and cytarabine 2'-triphosphate (3) were synthesized in the total yield of $75 \%$. These results suggest that the synthesis of novel anionic molecules of cytarabine containing phosphate groups is a promising area for the application to mononucleotide prodrug.

\section{EXPERIMENTAL}

\section{Materials and methods}

cyclo-Triphosphate, $\mathrm{Na}_{3} \mathrm{P}_{3} \mathrm{O}_{9}\left(\mathrm{P}_{3 \mathrm{~m}}\right)$, was prepared according to the previous paper ${ }^{15}$. Sodium 2,2-dimethyl-2-silapentane-5-sulfonate (DSS) was purchased form Sigma-Aldrich Chemical Co. (St. Louis, USA). Cytarabine and other reagents were purchased from Wako Chemicals (Osaka, Japan).

${ }^{31} \mathrm{P}$ NMR spectra with and without broad band ${ }^{1} \mathrm{H}$ decoupling and ${ }^{31} \mathrm{P}-{ }^{1} \mathrm{H}$ 2D HMBC spectra were obtained with a Varian INOVA-500 spectrometer using $85 \% \mathrm{H}_{3} \mathrm{PO}_{4}$ as an external standard.

HPLC analysis was carried out with a JASCO HPLC system consisting of a PU-2080i pump, a co-2060 Plus column oven, a V-530 UV-visible detector (JASCO, Japan). A column $(150 \times 6.0$ $\mathrm{mm}$ I.D.) packed with the polystyrene-based 
anion-exchanger (TSK gel, SAX, $5 \mu \mathrm{m}$, TOSOH, Japan) was used. The column temperature was maintained at $40{ }^{\circ} \mathrm{C}$. An isocratic elution technique using $0.33 \mathrm{M}$ potassium chloride solution was employed. The flow rate of the eluent was $1.0 \mathrm{~mL}$ $\min ^{-1}$. The UV absorbance of the effluent was monitored continuously at $271 \mathrm{~nm}$. The system control, data collection, and data analysis were carried by JASCO-BORWIN system.

The semipreparative HPLC was carried out with a JASCO HPLC system consisting of a PU-2080i pump, a co-2060 Plus column oven, a Ubest-30 UV-visible detector (JASCO, Japan). An ODS-3 column $(250 \times 10.0 \mathrm{~mm}$ I.D., $5 \mu \mathrm{m}$, GL Science, Japan) was used and the column temperature was maintained at $40{ }^{\circ} \mathrm{C}$. The amount of sample injection was $1 \mathrm{~mL}$. An isocratic elution technique using $4 \%$ methanol-0.002 $\mathrm{M}$ ammonium acetic acid solution was employed. The flow rate of the eluent was $4.0 \mathrm{~mL} \mathrm{~min}{ }^{-1}$. The UV absorbance of the effluent was monitored continuously at $271 \mathrm{~nm}$. The system control, data collection, and data analysis were carried by JASCO-ChromNAV system.

\section{The procedure for the syntheses of products 1 - 3}

The reaction of cytarabine $(0.06 \mathrm{M}, 10 \mathrm{~mL})$ with $\mathrm{P}_{3 \mathrm{~m}}(0.6 \mathrm{M}, 10 \mathrm{~mL})$ was carried out at $\mathrm{pH} 12$ by adding $6 \mathrm{M}$ sodium hydroxide aqueous solution at 25 ${ }^{\circ} \mathrm{C}$. After $25 \mathrm{~d}$, the reaction solution was subjected to semipreparative HPLC to yield products $\mathbf{1}-\mathbf{3}$. It was collected about $6 \mathrm{~min}$ from about $3 \mathrm{~min}$ at retention time. 20 times injection produced about $200 \mathrm{~mL}$ preparative solution. Then, the solution was concentrated to $10 \mathrm{~mL}$. For the purpose of desalting, an aqueous solution of the concentrate was passed over an InartSep C18 column (GL Science, Japan). Each $2.4 \mathrm{~mL}$ fraction was measured by HPLC, and the fractionated solution containing only products $\mathbf{1}-\mathbf{3}$ were dryed in vacuo.

Cytarabine 5'-triphosphate (product 1) : ${ }^{1} \mathrm{H} \mathrm{NMR}$ $\left(\mathrm{D}_{2} \mathrm{O}\right) \delta: 6.13\left(1 \mathrm{H}, \mathrm{d}, J_{\mathrm{H} 1^{\prime}, \mathrm{H} 2^{\prime}}=5.0 \mathrm{~Hz}, \mathrm{H}-1^{\prime}\right), 4.33$

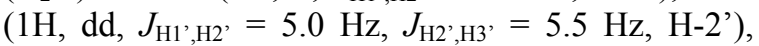
$4.19\left(1 \mathrm{H}, \mathrm{dd}, J_{\mathrm{H}^{\prime}, \mathrm{H} 3^{\prime}}=5.5 \mathrm{~Hz}, J_{\mathrm{H} 3^{\prime}, \mathrm{H}{ }^{\prime}}=5.5 \mathrm{~Hz}, \mathrm{H}-3^{\prime}\right)$, $4.00\left(1 \mathrm{H}, \mathrm{m}, \mathrm{H}-4^{\prime}\right), 4.15\left(1 \mathrm{H}, \mathrm{m}, \mathrm{H}_{\mathrm{A}}-5^{\prime}\right), 4.18(1 \mathrm{H}, \mathrm{m}$, $\left.\mathrm{H}_{\mathrm{B}}-5^{\prime}\right), 7.79\left(1 \mathrm{H}, \mathrm{d}, J_{\mathrm{H} 4, \mathrm{H} 5}=7.5 \mathrm{~Hz}, \mathrm{H}-4\right), 6.00(1 \mathrm{H}, \mathrm{d}$, $\left.J_{\mathrm{H} 4, \mathrm{H} 5}=7.5 \mathrm{~Hz}, \mathrm{H}-5\right) . \quad{ }^{31} \mathrm{P} \mathrm{NMR}\left(\mathrm{D}_{2} \mathrm{O}\right) \delta:-9.6(1 \mathrm{P}, \mathrm{dt}$, $J_{\mathrm{P}_{\alpha}, \mathrm{P}_{\beta}}=19.0 \mathrm{~Hz}, J_{\mathrm{P}_{\alpha}, \mathrm{H}_{\mathrm{A}}{ }^{5}}=5.4 \mathrm{~Hz}, J_{\mathrm{P}_{\alpha}, \mathrm{H}_{\mathrm{B}}{ }^{5}}=5.4 \mathrm{~Hz}$, $\left.\mathrm{P}_{\alpha}\right),-20.0\left(1 \mathrm{P}, J_{\mathrm{P}_{\alpha}, \mathrm{P}_{\beta}}=19.0 \mathrm{~Hz}, J_{\mathrm{P}_{\beta}, \mathrm{P}_{\gamma}}=19.5 \mathrm{~Hz}, \mathrm{P}_{\beta}\right)$, $-4.74\left(1 \mathrm{P}, \mathrm{d}, J_{\mathrm{P}_{\beta}, \mathrm{P}_{\gamma}}=19.5 \mathrm{~Hz}, \mathrm{P}_{\gamma}\right)$.

Cytarabine 3'-triphosphate (product 2) : ${ }^{1} \mathrm{H}$ NMR

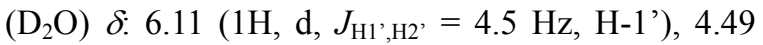
$\left(1 \mathrm{H}, \mathrm{dd}, J_{\mathrm{H} 1^{\prime}, \mathrm{H} 2^{\prime}}=4.5 \mathrm{~Hz}, J_{\mathrm{H} 2^{\prime}, \mathrm{H} 3^{\prime}}=2.5 \mathrm{~Hz}, \mathrm{H}-2^{\prime}\right)$,

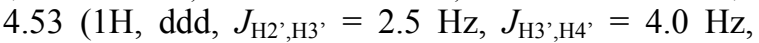
$\left.J_{\mathrm{P}_{\alpha}, \mathrm{H} 3},=9.0 \mathrm{~Hz}, \mathrm{H}-3^{\prime}\right), 4.15$ (1H, m, H-4'), 3.77 (1H, dd, $\left.J_{\mathrm{H}^{\prime}, \mathrm{H}_{\mathrm{A}} 5},=4.0 \mathrm{~Hz}, J_{\mathrm{H}_{\mathrm{A}} 5^{\prime}, \mathrm{H}_{\mathrm{B}} 5^{\prime}}=12.5 \mathrm{~Hz}, \mathrm{H}_{\mathrm{A}}-5^{\prime}\right)$, $3.85\left(1 \mathrm{H}, \mathrm{dd}, J_{\mathrm{H}^{\prime}, \mathrm{H}_{\mathrm{B}}{ }},=6.5 \mathrm{~Hz}, J_{\mathrm{H}_{\mathrm{A}} 5^{5}, \mathrm{H}_{\mathrm{B}}{ }^{5}}=12.5 \mathrm{~Hz}\right.$, $\left.\mathrm{H}_{\mathrm{B}}-5^{\prime}\right), 7.70\left(1 \mathrm{H}, \mathrm{d}, J_{\mathrm{H} 4, \mathrm{H} 5}=7.5 \mathrm{~Hz}, \mathrm{H}-4\right), 6.08(1 \mathrm{H}, \mathrm{d}$,
$\left.J_{\mathrm{H} 4, \mathrm{H} 5}=7.5 \mathrm{~Hz}, \mathrm{H}-5\right) . \quad{ }^{31} \mathrm{P} \mathrm{NMR}\left(\mathrm{D}_{2} \mathrm{O}\right) \delta:-10.6(1 \mathrm{P}$, $\left.\mathrm{dd}, J_{\mathrm{P}_{\alpha}, \mathrm{P}_{\beta}}=18.0 \mathrm{~Hz}, J_{\mathrm{P}_{\alpha}, \mathrm{H} 3},=9.0 \mathrm{~Hz}, \mathrm{P}_{\alpha}\right),-20.0(1 \mathrm{P}$, $\left.J_{\mathrm{P}_{\alpha}, \mathrm{P}_{\beta}}=18.0 \mathrm{~Hz}, J_{\mathrm{P}_{\beta}, \mathrm{P}_{\gamma}}=18.5 \mathrm{~Hz}, \mathrm{P}_{\beta}\right),-4.62(1 \mathrm{P}, \mathrm{d}$, $\left.J_{\mathrm{P}_{\beta}, \mathrm{P}_{\gamma}}=18.5 \mathrm{~Hz}, \mathrm{P}_{\gamma}\right)$.

Cytarabine 2'-triphosphate (product 3) : ${ }^{1} \mathrm{H}$ NMR

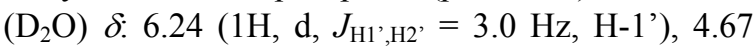
$\left(1 \mathrm{H}, \mathrm{m}, \mathrm{H}-2^{\prime}\right), 4.39\left(1 \mathrm{H}, \mathrm{m}, \mathrm{H}-3^{\prime}\right), 3.95(1 \mathrm{H}, \mathrm{m}$, H-4'), 3.74 (1H, m, $\mathrm{H}_{\mathrm{A}}-5^{\prime}$ ), 3.80 (1H, m, $\left.\mathrm{H}_{\mathrm{B}}-5^{\prime}\right), 7.61$ $\left(1 \mathrm{H}, \mathrm{d}, J_{\mathrm{H} 4, \mathrm{H} 5}=7.5 \mathrm{~Hz}, \mathrm{H}-4\right), 5.93\left(1 \mathrm{H}, \mathrm{d}, J_{\mathrm{H} 4, \mathrm{H} 5}=7.5\right.$ $\mathrm{Hz}, \mathrm{H}-5) .{ }^{31} \mathrm{P}$ NMR $\left(\mathrm{D}_{2} \mathrm{O}\right) \delta:-11.5\left(1 \mathrm{P}, \mathrm{dd}, J_{\mathrm{P}_{\alpha}, \mathrm{P}_{\beta}}=\right.$ $\left.19.0 \mathrm{~Hz}, J_{\mathrm{P}_{\alpha}, \mathrm{H} 2}=10.3 \mathrm{~Hz}, \mathrm{P}_{\alpha}\right),-20.0\left(1 \mathrm{P}, J_{\mathrm{P}_{\alpha}, \mathrm{P}_{\beta}}=19.0\right.$ $\left.\mathrm{Hz}, J_{\mathrm{P}_{\beta}, \mathrm{P}_{\gamma}}=19.5 \mathrm{~Hz}, \mathrm{P}_{\beta}\right),-4.57\left(1 \mathrm{P}, \mathrm{d}, J_{\mathrm{P}_{\beta}, \mathrm{P}_{\gamma}}=19.5 \mathrm{~Hz}\right.$, $\left.\mathbf{P}_{\gamma}\right)$.

\section{ACKNOWLEDGEMENTS}

The authors thank associate professor M. Sugiura of Kobe Pharmaceutical University for the measurements of ${ }^{31} \mathrm{P}$ and ${ }^{31} \mathrm{P}-{ }^{1} \mathrm{H} 2 \mathrm{D}$ (HMBC) NMR spectra.

\section{REFERENCES}

1. M. Higashigawa, H. Hori, T. Ohkubo, H. Kawasaki, T. Yoshizumi, M. Sakurai, Med. Oncol. \& Tumor Pharmacother., 7, 223 (1990).

2. M. Kukhanova, A. Krayevsky, W. Prusoff, Y.-C. Cheng, Curr. Pharm. Des., 6, 585 (2000).

3. W. Shen, J.-S. Kim, P. E. Kish, J. Zhang, S. Mitchell, B. G. Gentry, J. M. Breitenbach, J. C. Drach, J. Hilfinger, Bioorg. Med. Chem. Lett., 19, 792 (2009).

4. M. Tsuhako, M. Fujimoto, S. Ohashi, H. Nariai, I. Motooka, Bull. Chem. Soc. Jpn., 57, 3274 (1984).

5. M. Tsuhako, R. Kunitomi, Y. Baba, T. Miyajima, I. Motooka, Bull. Chem. Soc. Jpn., 64, 490 (1991).

6. M. Tsuhako, A. Nakajima, S. Ohashi, H. Nariai, I. Motooka, Bull. Chem. Soc. Jpn., 56, 1372 (1983).

7. H. Inoue, H. Nakayama, M. Tsuhako, Phosphorus Res. Bull., 12, 65 (2001).

8. H. Inoue, M. Watanabe, H. Nakayama, M. Tsuhako, Chem. Pharm. Bull., 46, 681 (1998).

9. H. Inoue, H. Nakayama, M. Tsuhako, Carbohydr. Res., 324, 10 (2000).

10. H. Inoue, M. Watanabe, H. Nakayama, M. Tsuhako, Chem. Pharm. Bull., 48, 802 (2000).

11. H. Inoue, N. Tone, H. Nakayama, M. Tsuhako, Chem. Pharm. Bull., 50, 1453 (2002).

12. H. Inoue, N. Tone, H. Nakayama, M. Tsuhako, Phosphorus Res. Bull., 11, 19 (2003).

13. H. Inoue, N. Tone, H. Nakayama, M. Tsuhako, Carbohydr. Res., 338, 2067 (2003).

14. H. Inoue, Y. Baba, T. Furukawa, Y. Maeda, M. Tsuhako, Chem. Pharm. Bull., 41, 1895 (1993).

15. M. Tsuhako, N. Fujita, A. Nakahama, T. Matsuo, M. Kobayashi, S. Ohashi, Bull. Chem. Soc. Jpn., 53, 1968 (1980). 